\title{
Influence of Seasonal Variations of Temperature and Light on the Growth Rate of Cultures and Natural Populations of Intertidal Diatoms*
}

\author{
W. Admiraal and H. Peletier \\ Department of Systematic Botany, State University of Groningen, P. O. Box 14,9750 AA Haren, The Netherlands
}

\begin{abstract}
Cultures of four benthic diatom species (Navicula salinarum, Amphiprora cf. paludosa, N. arenaria, Gyrosigma spencerii) were kept at the surface of a mudflat in order to measure division rates. During incubations in the period of December to June the mean temperature was the predominant factor regulating cell division rate. Immersion of the mudflat with very turbid tidal water was an important factor only at a low-level mudflat station during winter and early spring. Strong temperature fluctuations during incubations, with periods of frost in winter and periods of insolation during hot summer weather, did not interrupt growth of the cultures. Hence high temperatures and high irradiance values are unlikely to be the direct cause of the summer minimum in population density that is frequently observed in the estuary. After the winter minimum the increase in population density was measured at three levels of the mudflat. At the high-level station the density increased in January at still very low temperatures, whereas at the mid-and low-level stations this increase started in March. This observation indicates that the emersion time of the mudflat and hence its exposure to full daylight is an important factor in the development of the spring bloom. The density of the diatom populations in the $0.5 \mathrm{~cm}$ top layer of the sediment increased only at a very low rate (with maximum rates of ca. 0.1 doublings $\mathrm{d}^{-1}$ ). Low photosynthetic rates of natural diatom populations in the sediment core are the cause of these low doubling rates of natural populations on the mudflat. Dispersal of diatom cells into the sediment is probably responsible for the decreased photosynthetic rates and, consequently, for the low doubling rates of sediment-inhabiting diatoms.
\end{abstract}

\section{INTRODUCTION}

Measurements of primary production by benthic diatom populations in the Dutch Wadden Sea were used to show the quantitative importance of these organisms in the carbon-flux within the ecosystem (Cadée and Hegeman, 1974, 1977; van Es, 1977; Colijn, 1978). In spite of these contributions and comparable studies on production of intertidal diatom populations, most of the dynamic characteristics of these populations have remained obscure. Kinetic parameters - such as the rate of increase of populations, the photosynthetic rate per unit algal biomass, the rate of disappearance of cells or biomass by grazing, or the overall rate of turn-over - are essentially unknown. As pointed out by Schöne (1977) for marine phytoplankton, these problems can be solved only in part by classical methods of production biology. Measurements on cell division rates in natural phytoplankton

- Publication Number 21 of the project 'Biological Research of the Eems-Dollard Estuary'. populations are needed, but are technically difficult to achieve (Schöne, 1977)

We think that answers to the following questions are essential in order to obtain better insight into the population dynamics of diatoms on an intertidal mudflat:

(1) At what rate can diatom cells divide at the surface of sediments during various seasons, when nutrient depletion and cell burial factors are absent?

(2) What is the effect of mudflat immersion in turbid tidal water, with its concomitant reduction of the photoperiod, on cell division rate?

(3) At what rate do natural populations increase during favourable periods?

(4) What is the production-biomass ratio of natural populations and what is the possible relation of this ratio to cell division rate?

(5) At what rate are diatom cells removed from active populations, e. g. by grazing and burial?

The present paper reports on experiments and observations pertaining mainly to the first four questions. Data on the division rate of diatoms in field incubators 
and on the growth rate of natural populations, as well as information from earlier production studies, were used to construct a tentative picture of groth dynamics for a diatom population on an estuarine mudflat.

\section{MATERIALS AND METHODS}

\section{Environmental Conditions}

The investigations were carried out at three stations on a small intertidal mudflat in the Eems-Dollard estuary, a part of the Wadden Sea (Fig. 1). The mean tidal range in the area is $2.5 \mathrm{~m}$. The three mudflat stations were situated on different levels of the mudflat and hence their emersion periods were different. Emersion periods were calculated for each tidal cycle using registrations of the water level (Netherlands Department of Public Works, Rijks Waterstaat). Sky irradiance was measured by a Kipp solarimeter placed
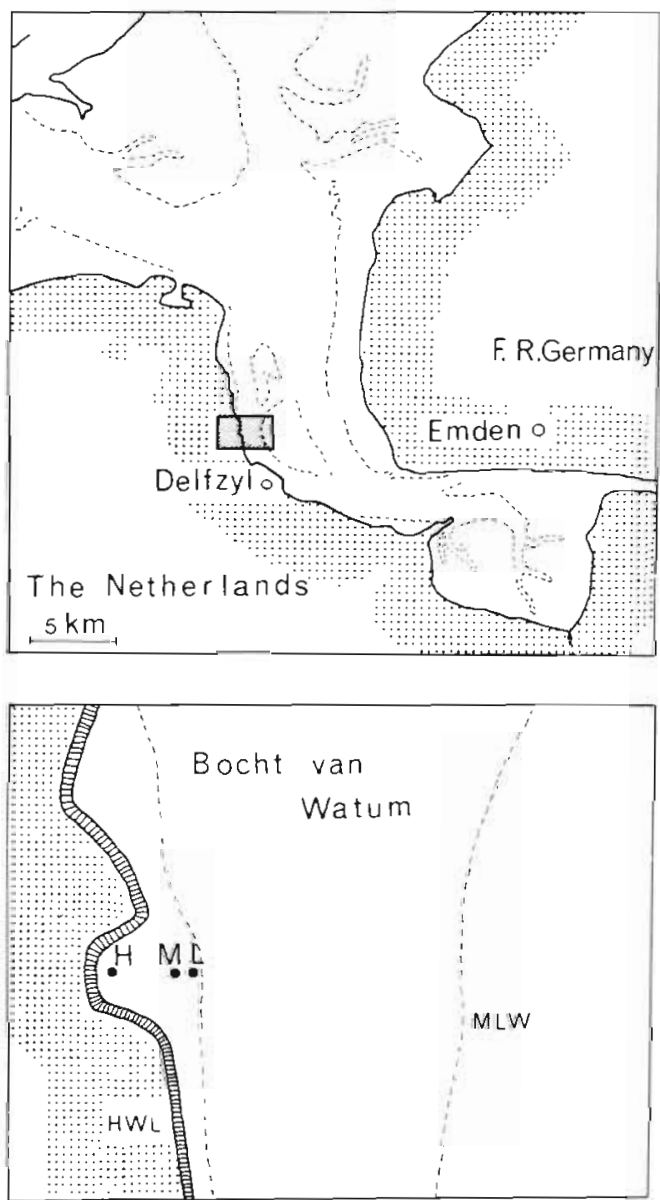

Fig. 1. Location of stations on intertidal mudflat of EemsDollard estuary. H: high-level station, $\mathrm{M}$ : mid-level station, L: low-level station. HWL: high-water line and dike, MLW: mean low-water line near the border of the estuary. From solarimeter readings the total daily irradiance was obtained, as well as the daily period in which the irradiance level was higher than $0.03 \mathrm{~J} \mathrm{~cm}^{-2} \mathrm{~min}^{-1}$. For each of the three stations the length of the daily photoperiod was calculated from the overlap of the emersion period at the station and the light period as shown by solarimeter readings. The turbidity of the tidal water, which immerses the mudflat, is generally high. For that reason the irradiance reaching the mudflat surface during periods of emersion is of paramount importance. However, during calm weather rather clear water may immerse the mudflat so that a water layer of $0.5 \mathrm{~m}$ may still allow $20-50 \%$ of the incident irradiance to reach the mudflat surface.

The water temperature in the estuarine tidal currents were determined at a distance of $5 \mathrm{~km}$ from experimental stations and measured by the Netherlands Department of Public Works. Air temperatures (daily mean values) were obtained from the Dutch Metereological Institute (KNMI) and measured at Eelde Airport (30 km to the SW).

\section{Field Incubations}

Four diatoms - Navicula salinarum Grunow, Amphiprora cf. paludosa W. Smith, Navicula arenaria Donkin and Gyrosigma spencerii (W. Smith) Cleve -

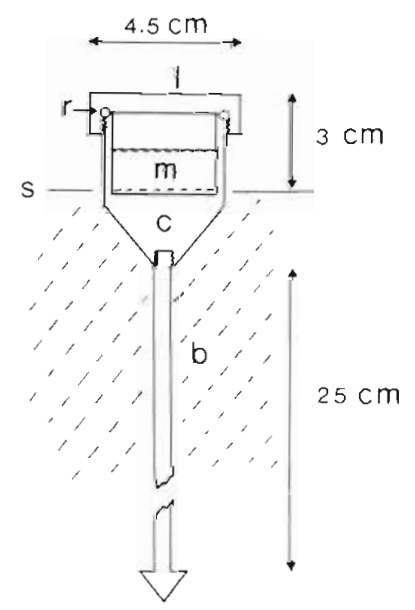

Fig. 2. Field incubator positioned in sediment. b: stabilization bar; c: Perspex container; 1: Perspex lid; m: culture medium $r$ : sealing ring; s: sediment surface

were grown in incubators at the sediment surface of an intertidal flat. The incubators (Fig. 2) contain an airand water-tight chamber (volume $20 \mathrm{ml}$ ) filled with 10 $\mathrm{ml}$ of culture medium with an inoculum of diatoms. A $0.5 \mathrm{~mm}$ thick layer of coarse grained sand was spread 
out over the bottom of the incubator and served as a substratum for the diatom cells. As culture medium enriched artificial sea water was used as described previously (Admiraal, 1977c).

Growth curves were obtained using 8 identical cultures placed on the mudflat. Growing cells were suspended in low concentrations (ca. 1000 cells $\mathrm{ml}^{-1}$ ) into fresh medium and $10 \mathrm{ml}$ of this suspension was pipetted into each incubator. At intervals, two of these cultures were collected from the field and cell concentrations of the cultures determined microscopically using a counting chamber. Growth curves were recorded when the cultures were relatively dilute, the concentrations varying from 1000 to 200000 cells ml $\mathrm{ml}^{-1}$.

The incubators were pressed into the sediment so that the bottom of the incubator chamber was at the same level as the sediment surface (Fig. 1). The incubators remained undisturbed in the field during periods of up to one month. While some sediment around the incubator was flushed away, neither sediment nor other algae settled on the lid during the incubation periods. The quantum irradiance within the incubator chamber amounted to roughly $75 \%$ of the outside quantum irradiance, but occasionally the light reduction reached a value of $50 \%$ under a lid covered with condensation droplets. The temperatures inside the incubators differs less than $1 \mathrm{C}^{\circ}$ from those of the sediment surface, even in sunshine.

\section{Density of Natural Populations}

The density of natural microphytobenthos on the mudflats was measured as the chlorophyll a concentration in the sediment. Six replicate $0.5-\mathrm{cm}$ deep cores (diameter $2.4 \mathrm{~cm}$ ) were collected from every station and extracted in $90 \%$ acetone. The chlorophyll a concentration was calculated according to Lorenzen (as in Admiraal, 1977a).

\section{RESULTS}

The populations of benthic diatoms on the mudflat developed from sparse populations in winter to very dense populations in late spring (Fig. 3). In this period the increase in population density (expressed as $\mathrm{mg}$ chlorophyll a $\mathrm{m}^{-2}$ sediment) amounted to a factor of 5-10. The populations at the high-level, mid-level and low-level stations developed differently. At the highlevel mudflat station the density had already increased appreciably in January, when the temperature was still very low, whereas at the mid-level and the low-level station the increase in population density started in February-March and March-April, respectively. Since

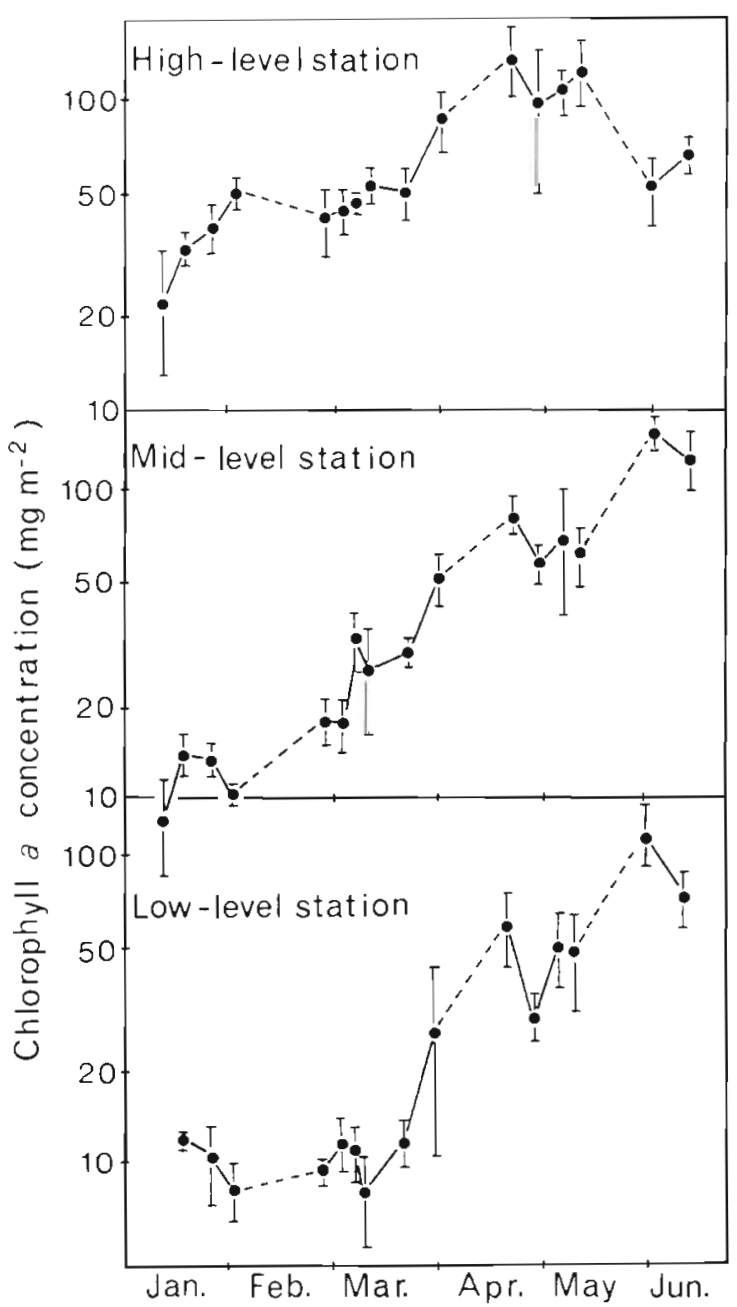

Fig. 3. Density of micro-algal populations at three levels of intertidal mudflat. January 12 to June 5, 1978. Density measured as chlorophyll a concentration in top $0.5 \mathrm{~cm}$ of sediment. Vertical bars: standard deviation ( $n=6)$; broken lines: periods of infrequent sampling

it is unlikely that the mean temperature on the three levels of the mudflat differed much, the shorter lightperiod at the lower stations are thought to have been responsible for the later start of the spring bloom at these stations.

The doubling rate of chlorophyll a concentration in the sediment was calculated from Figure 3. For each period between the two samplings this doubling rate was calculated, except for periods with infrequent sampling. The doubling rate of chlorophyll a concentration in the sediment was used to indicate periods of increase or decrease in natural populations (Fig. 6). The doubling rate of chlorophyll a concentration is most likely similar to the doubling rate of diatom biomass, since the carbon to chlorophyll a ratio in diatom samples was constant in early spring (V. N. de Jonge, personal communication). Figures 4 and 5 show 


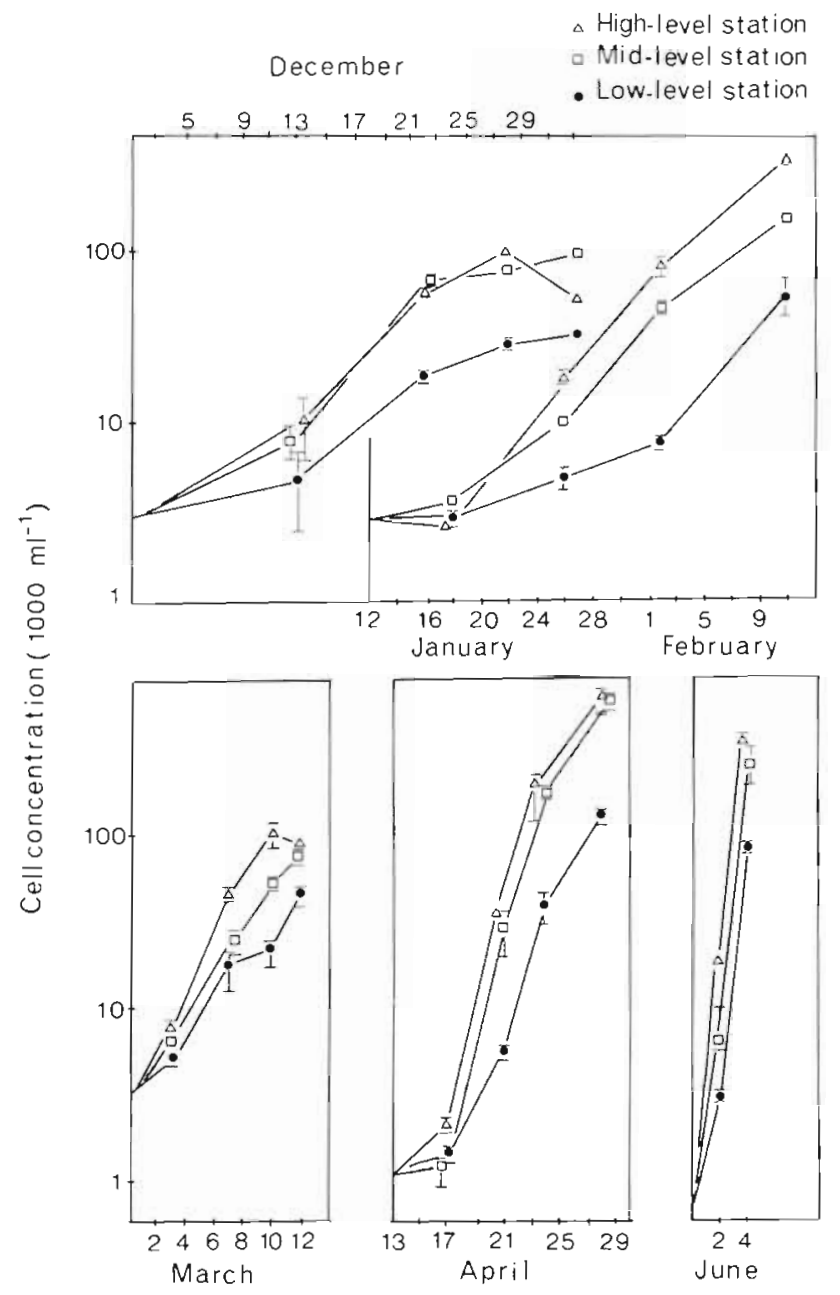

Fig. 4. Navicula salinarum. Growth curves of cultures recorded during five periods of incubation at three mudflat levels. Vertical bars: difference in cell concentration between duplicate cultures

growth curves of four diatom species kept in field incubators at the mudflat surface. The incubation of cultures on the mudflat were carried out in the same period as the density measurements of natural mudflat populations.

The division rates of Navicula salinarum (expressed as number of divisions per day) were calculated from Figure 4 for each period between two samplings of the cultures. This calculation was not carried out on the first period of each incubation, because this period encompassed the lag-phase of the cultures. In two cases also the last period was not used for the calculations, because the cell densities decreased after reaching an upper density level. The division rates of $N$. salinarum, calculated for the short period between two samplings was used only to show the possible relation between daily fluctuations in physico-chemical conditions and the division rate of $N$. salinarum. Figure 6 shows the calculated doubling rates of chlorophyll a concentration in the sediment and the calculated division rates of $N$. salinarum, together with a series of environmental conditions that were measured during the observation period.

The growth curves in Figures 4 and 5 were also used for graphical estimation of cell division rates of four diatom species. These estimates, pertaining to the complete growth cycle, are presented in Table 1.

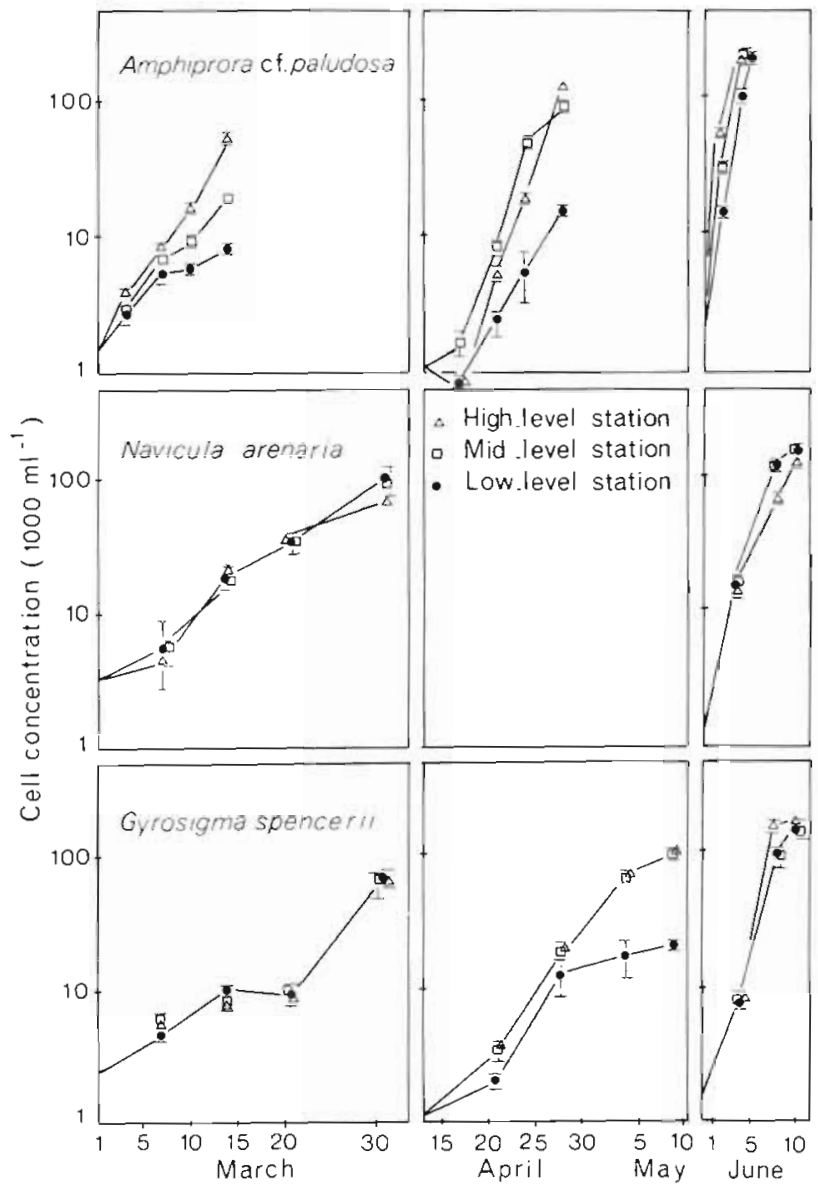

Fig. 5. Growth curves of three diatom species, incubated at three levels. Vertical bars: difference in cell concentration between duplicate cultures

\section{CONCLUSIONS AND DISCUSSION}

\section{Influence of Temperature and Light on Cell Division Rate in Cultures}

Observations on cell division rate of diatom cultures incubated at the mudflat surface lead to the conclusion that the four benthic diatom species tested are very eurythermal. The cell division rates (Table 1) measured in these field incubations at mean temperatures between $0^{\circ}$ and $22^{\circ} \mathrm{C}$ (Fig. 6) were roughly the same as 
Table 1. Cell division rates in diatom cultures at sediment surface. Incubation periods: winter 1977 to summer 1978 . Division rates (number of divisions day ${ }^{-1}$ ) calculated from angle of straight line drawn through growth curves (Figs. 4 and 5). Left part of table: incubation periods of rapidly growing species, right part, of slowly growing species. h: high-level station, m: mid-level station, 1: low-level station. n. d.: not determined

\begin{tabular}{|c|c|c|c|c|c|c|c|}
\hline $\begin{array}{l}\text { Incubation } \\
\text { period }\end{array}$ & $\begin{array}{c}\text { Station } \\
\text { level }\end{array}$ & $\begin{array}{c}N . \\
\text { salinarum }\end{array}$ & $\begin{array}{c}\text { A. cf. } \\
\text { paludosa }\end{array}$ & $\begin{array}{l}\text { Incubation } \\
\text { period }\end{array}$ & $\begin{array}{c}\text { Station } \\
\text { level }\end{array}$ & $\begin{array}{c}N . \\
\text { arenaria }\end{array}$ & $\begin{array}{c}G . \\
\text { spencerii }\end{array}$ \\
\hline $\begin{array}{lc}\text { Dec. } & 1-J a n .2 \\
1977 & 1978\end{array}$ & $\begin{array}{c}\mathrm{h} \\
\mathrm{m} \\
\mathrm{l}\end{array}$ & $\begin{array}{l}0.34 \\
0.34 \\
0.14\end{array}$ & n. d. & & & n.d. & n. $d$. \\
\hline Jan. 12-Feb. 11 & $\begin{array}{c}\mathrm{h} \\
\mathrm{m} \\
\mathrm{l}\end{array}$ & $\begin{array}{l}0.29 \\
0.24 \\
0.16\end{array}$ & n.d. & & & n.d. & n.d. \\
\hline Feb. 28-March 14 & $\begin{array}{c}\mathrm{h} \\
\mathrm{m} \\
\mathrm{l}\end{array}$ & $\begin{array}{l}0.53 \\
0.48 \\
0.32\end{array}$ & $\begin{array}{l}0.42 \\
0.27 \\
0.17\end{array}$ & Feb. 28-March 31 & $\begin{array}{c}\mathrm{h} \\
\mathrm{m} \\
\mathrm{l}\end{array}$ & $\begin{array}{l}0.16 \\
0.16 \\
0.16\end{array}$ & $\begin{array}{l}0.16 \\
0.16 \\
0.16\end{array}$ \\
\hline April $13-28$ & $\begin{array}{c}\mathrm{h} \\
\mathrm{m} \\
\mathrm{l}\end{array}$ & $\begin{array}{l}0.95 \\
0.95 \\
0.71\end{array}$ & $\begin{array}{l}0.63 \\
0.63 \\
0.38\end{array}$ & April 13-May 10 & $\begin{array}{c}\mathrm{h} \\
\mathrm{m} \\
\mathrm{l}\end{array}$ & n.d. & $\begin{array}{l}0.27 \\
0.27 \\
0.20\end{array}$ \\
\hline May 31-June 5 & $\begin{array}{c}\mathrm{h} \\
\mathrm{m} \\
\mathrm{l}\end{array}$ & $\begin{array}{l}2.2 \\
2.2 \\
1.8\end{array}$ & $\begin{array}{l}2.8 \\
2.5 \\
1.8\end{array}$ & May 31-June 10 & $\begin{array}{c}\mathrm{h} \\
\mathrm{m} \\
\mathrm{l}\end{array}$ & $\begin{array}{l}0.7 \\
0.9 \\
0.9\end{array}$ & $\begin{array}{c}0.8 \\
0.8 \\
0.8\end{array}$ \\
\hline
\end{tabular}

cell division rates measured in cultures kept at comparable constant temperatures between $4^{\circ}$ and $25^{\circ} \mathrm{C}$ in the laboratory (Admiraal, 1977a). Even periods of frost (February 1978, Fig. 6), during which ice crusts formed at the mudflat surface failed to inhibit cell division in the cultures. During periods of hot, sunny weather averaging air temperatures of $22^{\circ} \mathrm{C}$ (Fig. 6), the highest air temperatures of $29^{\circ} \mathrm{C}$ (and occasionally higher temperatures at the mudflat surface) produced the highest cell division rates. These observations apparently contradict indications that some benthic diatoms are inhibited by high summer temperatures (Hopkins, 1964). The reason for this is that none of the four species used for the present experiments is sensitive to high temperatures and irradiance levels as is, for instance, Navicula flanatica (Admiraal and Peletier, 1980)

Cell division rates of cultures, incubated at the highlevel mudflat station, are regulated primarily by the temperature of the mudflat and not by short lightperiods or limiting irradiance values. The cell division rates of cultures incubated at the high-level mudflat station were often similar to cell division rates of cultures incubated at the mid-level station, which receives shorter lightperiods (Table 6) and hence smaller amounts of irradiance than the high-level station. The dominating importance of temperature for division rates of cultures can also be shown by comparing division rates of cultures during the incubation periods in April and June (Fig. 6, Table 1). In the two periods the light conditions were similar, but the mean temperature was about $10{ }^{\circ} \mathrm{C}$ higher during incubations in June (Fig. 6). Hence the much higher division rates in June, as compared with those measured in April, must be ascribed to the influence of higher temperatures in the June period.

At the low-level mudflat station, sub-optimal light conditions - in addition to temperature - may have limited the division rate of the diatom cultures. During the first two incubation periods, cultured Navicula salinarum cells kept at the low-level station divided much more slowly than cells cultured at the high-level station (Table 1). The difference in division rates among low-level and high-level incubations gradually diminished throughout the spring (Table 1). Since it is unlikely that the mean temperature at the three mudflat levels differed appreciably, the shorter light periods at the low-level station, in addition to the low daily irradiance values in winter and early spring, must have been responsible for the relatively low division rates of $N$. salinarum at the low-level station. This conclusion is supported by the observation that parts of the growth cycle with very low division rates of $N$. salinarum in December (observed at three stations) and in January (observed at the low-level station) coincide with very short or no light periods at the mudflat stations (Fig. 6). Also during March 7-10, three days with very low daily irradiance levels (March 7,8 and 10), in addition to rather short light periods (Fig. 6) seem to have been responsible for the very low division rates of cultured N. salinarum (Fig. 6) and Amphiprora cf. paludosa (Fig. 5), especially when these were incubated at the 

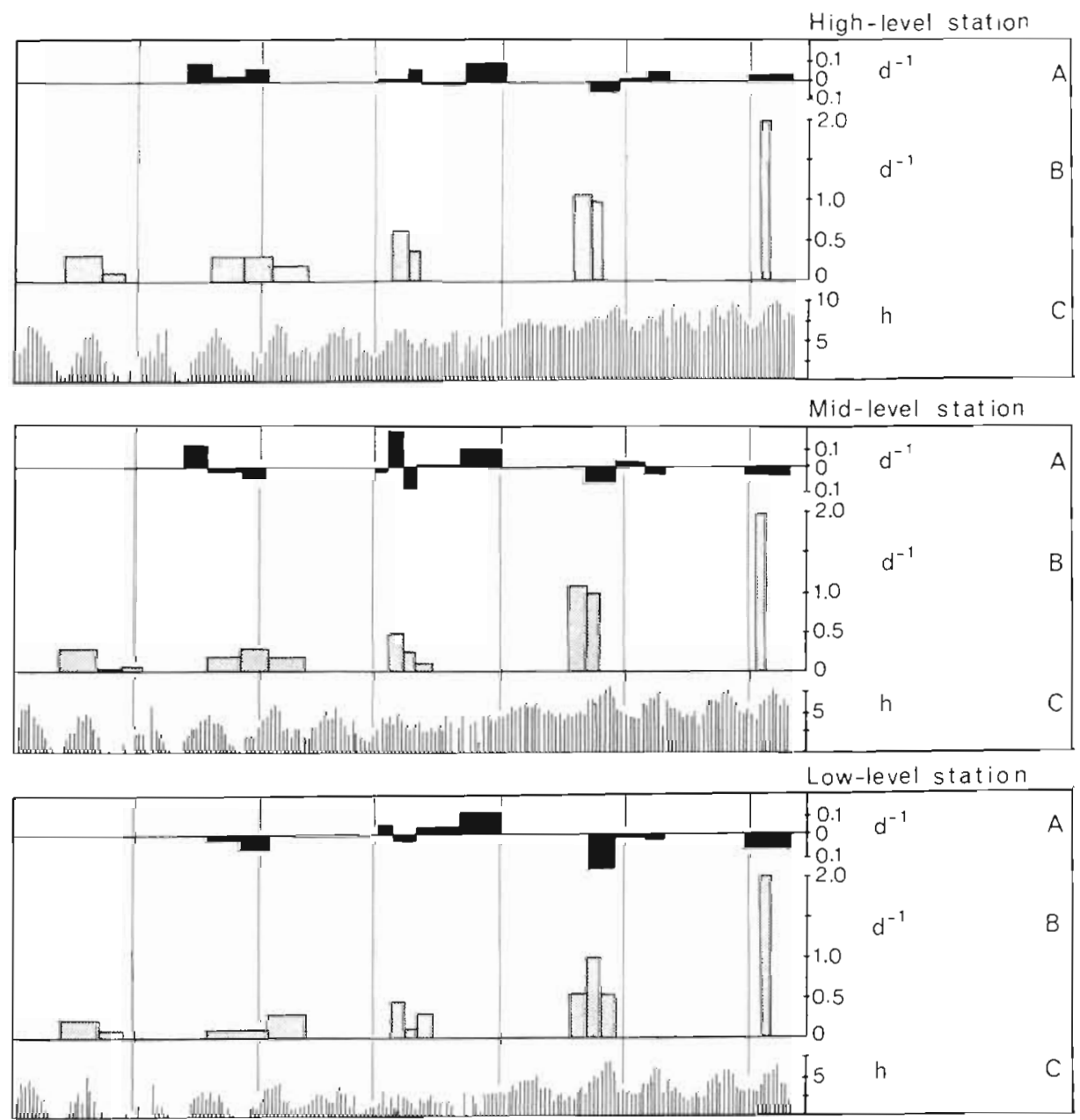

Environmental conditions

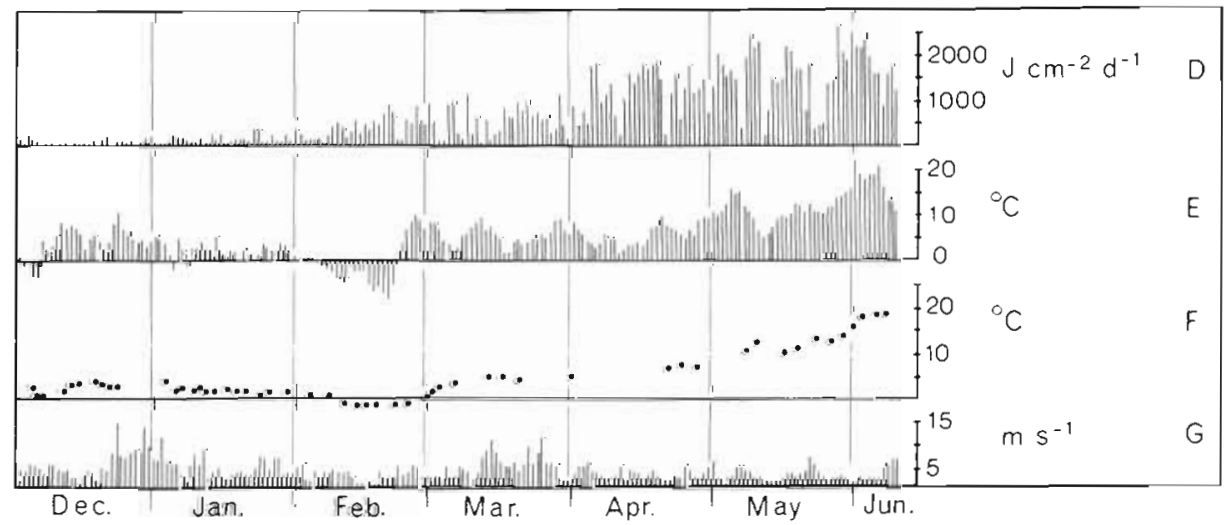

Fig. 6. Navicula salinarum. Temporal variation in number of doublings $d^{-1}$. A: natural diatom populations; B: number of divisions $\mathrm{d}^{-1}$ in cultures; $\mathrm{C}$ : light periods calculated for each day, separately for high-, mid-, and low-level station. Other environmental conditions shown in lower section. D: sky irradiance; $E$ : air temperature (daily mean value); F: water temperature; $\mathrm{G}$ : wind velocity. Doubling rate of natural populations calculated from chlorophyll a concentrations in sediment (Fig. 3). Division rates calculated from growth curves (Fig. 4) 
low- and mid-level mudflat stations. The decreasing density of the natural population at these low- and mid-level mudflat stations in the period of March 7-10 may also have been caused by retarded diatom growth.

From March to June the division rates of Navicula salinarum and Amphiprora cf. paludosa cultures, incubated at the low-level station, approach the division rates recorded at the high-level station. This indicates that light limitation diminishes with the seasonal increase of daily irradiance values and light periods (Fig. 6). Yet, the division rates of $N$. arenaria and Gyrosigma spencerii were virtually the same, when these species were cultured either at the high-or lowlevel mudflat stations during March to June (Table 1). The response of $N$. arenaria and $G$. spencerii (from March to June) may have been caused by their capacity to use lower irradiance values or shorter lightperiods more efficiently than the other species. Because of the relatively low division rates of these two species, several photoperiods may be used for completing one division cycle. Species-specific differences in the capacity to grow under sub-optimal light conditions are also shown by the following results of a previous investigation on $N$. arenaria and $A$. cf. paludosa (Admiraal, 1977a). A culture of $N$. arenaria reached its highest division rate at a quantum irradiance of ca. 2.5 $\mathrm{E} \mathrm{m}^{-2}$ day $^{-1}$ (supplied during a photoperiod of $16 \mathrm{~h}$ and a temperature of $20^{\circ} \mathrm{C}$ ), whereas a culture of $A$. cf. paludosa needed a quantum irradiance of at least $4 \mathrm{E}$ $\mathrm{m}^{-2}$ day ${ }^{-1}$ to reach its highest division rate. At photoperiods of only $4 \mathrm{~h}$ and a temperature of $20^{\circ} \mathrm{C}$ the division rate of $N$, arenaria was higher than that of $A$. cf. paludosa, whereas under all other combinations of temperature and lightperiods tested the division rate of A. cf. paludosa was the highest. These two observations support the conclusion that $N$. arenaria uses short photoperiods and low irradiance levels more efficiently for its divisions than $A$. cf. paludosa.

\section{Development of Population Density During Spring}

The spring bloom of benthic diatoms at the highlevel mudflat station started as early as January when temperatures were still between $0^{\circ}$ and $5{ }^{\circ} \mathrm{C}$. At the low-level station, the spring bloom did not start before the middle of March, when temperatures had increased to $5^{\circ}-10^{\circ} \mathrm{C}$. This observation suggests that the vernal increase in population density is triggered by increasing irradiance levels at the mudflat surface and not by increasing temperature. The relatively short daily lightperiods at the low-level station (Fig. 6) may explain why the diatom bloom at this station started later than at the high-level station. A similar phenomenon was observed by Gieskes and Kraay (1975) during phytoplankton spring bloom in coastal waters of the North Sea. Gieskes and Kraay showed that the vernal increase was initiated in early spring in the clearer offshore waters and then moved successively into the more turbid near-shore waters, as the incident irradiance increased during spring.

Dijkema (1975) observed dense diatom populations on the highest parts of an intertidal flat in the EemsDollard estuary during winter, while at the same time a sheltered but lower part of the same mudflat was inhabited only by a thin population. In summer, on the other hand, this low, sheltered part of the mudflat was covered by dense diatom populations, whereas the higher parts were only thinly inhabited. These observations by Dijkema (1975) and the present observations on the early stages of the spring bloom show that the emersion time of the mudflat and hence the length of the lightperiod are important factors in the development of dense diatom populations on the sediment surface.

Several factors are of importance for the development of diatom populations on mudflats, including diatom growth rate, grazing and sediment-surface stability. While the exact effects of these factors cannot be measured accurately yet, our results indicate the predominant importance of growth rate in natural populations. The highest densities of the diatom populations, amounting to ca. $100 \mathrm{mg}$ chlorophyll a $\mathrm{m}^{-2}$, were reached on April 24 at the high-level station and on May 30 at the low-and mid-level stations. In May the density at the highest station decreased, thus initiating the transition to the summer minimum, which is observed frequently in the estuary (Colijn, 1978). The excellent growth of cultures incubated on the mudflat in June shows that this summer minimum can hardly be explained by inhibitorily high temperature and irradiance. Other potential reasons for the summer minimum in population density are: grazing activity of benthic animals and/or local depletion of nutrients, such as silicate or inorganic carbon, in packed cell layers of diatoms.

\section{Regulation of Photosynthesis and Growth in Natural Populations}

In this investigation and that of Colijn (1978) carried out in the Eems-Dollard estuary, the top $0.5 \mathrm{~cm}$ layer of the sediment was sampled for determination of microphytobenthos density. The population in this layer was taken arbitrarily as 'active' population, because these cells are supposed to reach the $2-4 \mathrm{~mm}$ thick illuminated top layer of the sediment (Taylor, 1964; Fenchel and Staarup, 1971) intermittently, whereas large numbers of diatoms in deeper layers (Aleem, 
Table 2. Rates of photosynthesis in natural diatom populations incubated in intact sediment cores (I), in suspensions after isolation from sediment (II), and in sediment cores partly spread out (III). Rates expressed per unit chlorophyll $a$ or per sediment surface area. Samples kept at (nearly) saturating irradiance levels and at the temperatures indicated

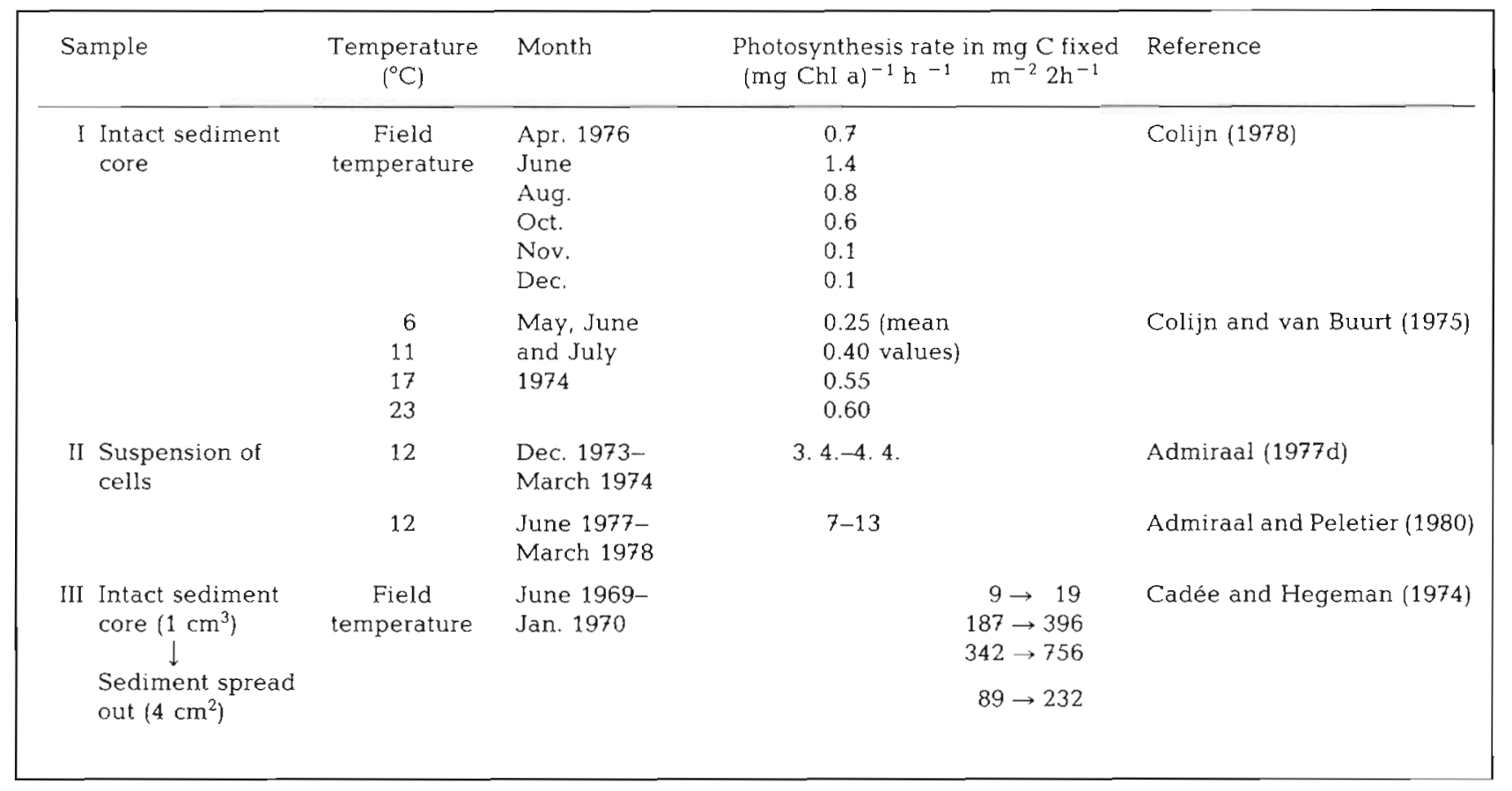

1950; Taylor and Gebelein, 1966; Steele and Baird, 1968; Fenchel and Staarup, 1971; Cadée and Hegeman, 1974) may be buried for prolonged periods.

During our observations in early spring the estimated doubling rates of natural diatom populations in the top $0.5 \mathrm{~cm}$ sediment layer were 3-10 times lower than doubling rates of cultures incubated on the mudflat (Table 6). Nutrient depletion is unlikely to be the cause of the low growth rates of the sparse spring populations of benthic diatoms in the estuary (Admiraal, 1977b). During early spring, when the temperature is still very low, animal grazing is unlikely to be of quantitative importance. Finally, while strong currents and sediment disturbance during gales might cause a temporary check to diatom growth, they would not prevent high doubling rates during periods of calm weather. The following calculations indicate that the low doubling rates of natural populations were probably caused by low photosynthesis rates.

Table 2 shows that the rate of photosynthesis of natural benthic diatom populations is greatly stimulated when the sediment column is spread out and even more so when the diatoms are isolated from the sediment and suspended. The improved illumination of cells during these treatments is probably the main cause of the increased rate of photosynthesis per unit chlorophyll. An additional reason might be the improved supply of nutrients (e. g. carbon dioxide) and diffusion of waste products (e. g. oxygen). Colijn (1978) measured, in the course of one year, photosynthesis rates of diatom populations that ranged from 0.1 to 1.4 mg C (mg chlorophyll a) $)^{-1} \mathrm{~h}^{-1}$. He used intact, $0.5-\mathrm{cm}$ deep cores of sediment, obtained from the same mudflat studied in the present investigation. During a lightperiod of $5 \mathrm{~h}$ (Fig. 6) these populations assimilated $0.5-7.0 \mathrm{mg} \mathrm{C}$ (mg chlorophyll a $)^{-1}$. The ratio of carbon to chlorophyll a content in epipelic diatom samples from the mudflat is ca. 40 (V. N. de Jonge, personal communication). Thus, the daily carbon fixation of the diatom populations amounts to ca. $0.012-0.18 \mathrm{mg} C$ (mg $\mathrm{C}$ biomass) $)^{-1}$. Even if the respiratory losses of the populations are ignored, this photosynthesis rate is so low that it can only account for $0.012-0.18$ biomass doublings day ${ }^{-1}$. The highest potential doubling rate of 0.18 accords roughly with the highest doubling rate of 0.1 , estimated for natural populations in the field (Fig. 6). The photosynthetic rates of isolated and suspended diatom populations are so high (Table 2 ) that a biomass doubling rate of $0.4-1.6$ doublings $\mathrm{d}^{-1}$ can be expected under optimum conditions at the mudflat surface. Actually, these doubling rates are reached by diatom cultures placed on the mudflat. Hence, the observed low doubling rates of the natural populations during the early stages of spring bloom are probably caused by strongly decreased photosynthesis rates. The dispersal of diatom cells in the top $0.5 \mathrm{~cm}$ of the sediment 
and insufficient illumination are probably the main causes for these low photosynthesis rates.

Acknowledgements. We thank F. Ebbens for analytical help; Professor C. van den Hoek, for thorough review of the manuscript; Professor H. Veldkamp and Dr. P. de Wolf, for critical comments. F. Colijn supported various stages of the investigation and the State Department 'Rijks Waterstaat' contributed tidal data.

\section{LITERATURE CITED}

Admiraal, W. (1977a). Influence of light and temperature on the growth rate of estuarine benthic diatoms in culture. Mar. Biol. 39: 1-9

Admiraal, W. (1977b). Influence of various concentrations of orthophosphate on the division rate of an estuarine benthic diatom, Navicula arenaria, in culture. Mar. Biol. 42: $1-8$

Admiraal, W. (1977c). Tolerance of estuarine benthic diatoms to high concentrations of ammonia, nitrite ion, nitrate ion and orthophosphate. Mar. Biol. 43: 307-315

Admiraal, W. (1977d). Salinity tolerance of benthic estuarine diatoms as tested with a rapid polarographic measurement of photosynthesis. Mar. Biol. 39: 11-19

Admiraal, W., Peletier, H. (1979). Influence of organic compounds and light limitation on the growth rate of estuarine benthic diatoms. Br. J. Phycol. 14: 197-206

Admiraal, W., Peletier, H. (1980). Distribution of diatom species on an estuarine mudflat and experimental analysis of the selective effect of stress. (in preparation)

Aleem, A. A. (1950). The diatom community inhabiting the mudflats at Whitstable. New Phytologist 49: 174-188

Cadée, G. C., Hegeman, J. (1974). Primary production of the benthic microflora living on the tidal flats in the Dutch Wadden Sea. Neth. J. Sea Res. 8: 260-291

Cadée, G. C., Hegeman, J. (1977). Distribution of primary production of the benthic microflora and accumulation of organic matter on a tidal flat area, Balgzand, Dutch Wadden Sea. Neth. J. Sea Res. 11: 24-41
Castenholz, R. W. (1964). The effect of daylength and light intensity on the growth of littoral marine diatoms in culture. Physiol. Plant. 17: 951-963

Colijn, F. (1978). Primary productivity measurements in the Ems-Dollard estuary during 1975 and 1976. Publications and reports of the project 'Biological Research in the EmsDollard estuary'

Colijn, F., van Buurt, G. (1975). Influence of light and temperature on the photosynthetic rate of marine benthic diatoms. Mar. Biol. 31: 209-214

Dijkema, K. S. (1975). Verkennend onderzoek naar de invloed van abiotische faktoren op de benthische diatomeeën in de oostelijke Waddenzee. Publications and reports of the project 'Biological Research in the Ems-Dollard estuary'

Es, F. B. van (1977). A preliminary carbon budget for a part of the Ems estuary: The Dollard. Helgoländer wiss. Meeresunters. 30: 283-294

Fenchel, T., Staanup, B. J. (1971). Vertical distribution of photosynthetical pigments and the penetration of light in marine sediments. Oikos 22: 172-182

Gieskes, W. W. C., Kraay, G. W. (1975). The phytoplankton spring bloom in Dutch coastal waters of the North Sea. Neth. J. Sea Res. 9: 166-196

Hopkins, J. T. (1964). A study of the diatoms of the Ouse estuary, Sussex. III. The seasonal variation in the littoral epiphyte flora and the shore plankton. J. mar. biol. Ass. U. K. 44:613-644

Schöne, H. K. (1977). Die Vermehrungsrate mariner Planktondiatomeen als Parameter in der Okosystemanalyse. Habilitationsschrift, Botanisches Institut RWTH, Melateuer Strasse, D-5100 Aachen, F.R.G

Steele, J. H., Baird, I. E. (1968). Production ecology of a sandy beach. Limnol. Oceanogr. 13: 14-25

Taylor, R. W. (1964). Light and photosynthesis in intertidal benthic diatoms. Helgoländer wiss. Meeresunters. 10: 29-37

Taylor, R. W., Gebelein, C. D. (1966). Plant pigments and light penetration in intertidal sediments. Helgoländer wiss. Meeresunters. 13: 229-237

Williams, R. B. (1964). Division rates of salt-marsh diatoms in relation to salinity and cell size. Ecology 45: 877-886

This paper was submitted to the editor; it was accepted for printing on December 28,1979 . 